\title{
The use of whole exome sequencing to identify carriers of Mosaic Variegated Aneuploidy (MVA): A case study
}

\author{
Munirah T Aljaser ${ }^{1 *}$ and Shakir Bahzad ${ }^{2}$ \\ ${ }^{1}$ Farwaniya Hospital - MOH, Kuwait \\ ${ }^{2}$ Kuwait Medical Genetics Center, Kuwait
}

\begin{abstract}
Background: Whole-exome sequencing (WES) is a clinical diagnostic and research tool designed to identify and classify the arrangement of all protein-coding nuclear genes in the genome. Cases of infertility and recurrent miscarriages complicated by multiple-loop consanguinity may benefit from the implementation of whole-exome sequencing.

Case presentation: We report a case of a Kuwaiti consanguineous couple referred to the genetics department with a history of three live births followed by fourteen miscarriages, most of which occurred during the third and fourth months of gestation. The initial routine investigations including the blood tests, thyroid function, imaging, immunological and antibody profile, and chromosomal microarray of both parents were normal. The presence of multiple loops of consanguinity made making a correct diagnosis difficult. The option of whole-exome sequencing to examine the entire exome of both parents was proposed. After taking the patients consent, the WES results of the couple revealed them both to be carriers of a previously unreported heterozygous variant of the CEP57 mutation resulting in multiple pregnancies with type 2 mosaic variegated aneuploidy that were incompatible with life.
\end{abstract}

Methods: Whole-exome sequencing was agreed by the treating clinical geneticists as a suitable option to identify the presence of a possible genetic mutation. The age, gender, ethnicity, medical history, family history, consanguinity, laboratory investigation results, clinical interpretation and implication of the results have been documented.

Conclusion: The reported case of infertility and recurrent miscarriages associated with multiple-loop consanguinity showed no abnormalities using conventional diagnostic methods. The application of whole-exome sequencing for the couple revealed them to be carriers for the type 2 mosaic variegated aneuploidy syndrome gene CEP57. In cases of multiple-loop consanguinity, whole-exome sequencing should be considered to aid in the diagnosis of the genetic mutations.

\section{Introduction}

Mosaic variegated aneuploidy (MVA), also known as WarburtonAyane-Yeboa Syndrome, is classified by the Genetic and Rare Diseases (GARD) of the National Institute of Health (NIH) as a rare disease and has an autosomal recessive mode of inheritance [1]. MVA is classified into 2 types, MVA type 1 caused by BUB1B gene mutation and MVA type 2, which is less common and is caused by CEP57 gene mutation. Both types, however, result in defective chromosome separation during cell division [1].

The CEP57 gene plays a role in the stability and organization of cell spindle microtubules during cell division [2]. After the cell has duplicated the chromosomes, the spindle microtubules attach to the copies and pull them to opposite poles of the cell, ensuring that each new cell has one complete set of chromosomes; in MVA this organized separation does not occur resulting in mosaicism [2-4]. The CEP57 gene has also been linked to the transport of fibroblast growth factor 2 (FGF2), a signaling protein that regulates the development and growth of cells, along microtubules [2,5].

MVA is characterized by aneuploidy, most commonly presenting as monosomies or trisomies in cells. Due the random nature of the syndrome, the presentation varies from one case to the next. However, the most common features of MVA include intrauterine growth retardation (IUGR), microcephaly, brain abnormalities, and morphological anomalies such as low set ears and a broad nasal bridge
[2,3]. Additionally, MVA has been associated with certain malignancies such as rhabdomyosarcoma, leukemias, and Wilms tumor. ${ }^{1}$

\section{Case presentation}

A married couple, a 38-year-old Kuwaiti woman and her husband, were referred to the genetics department by their treating gynecologist due a series of multiple and unexplained miscarriages. The couple have been in a consanguineous marriage (first degree paternal cousins) for the past 15 years. The husband was assessed to be healthy and had no significant past medical history. The wife was known to have hypothyroidism which was well-controlled and was being treated with eltroxin $100 \mathrm{mcg}$, she follows-up regularly with her endocrinologist.

Her obstetric history revealed the wife to be G17 P3 T2 A14 L2. The first two pregnancies were one year apart, both pregnancies were full-term, healthy girls with no complications. The third pregnancy produced a premature male diagnosed with Dandy-Walker syndrome. He died at 2 and a half years of age because of medical complications related to his condition. No DNA was obtained. The subsequent twelve pregnancies ended in miscarriage, all occurring in the third and fourth

${ }^{*}$ Correspondence to: Munirah T Aljaser, Farwaniya Hospital - MOH, Kuwait, Tel: 96551379990, E-mail: m.t.aljaser@gmail.com

Received: June 08, 2018; Accepted: June 20, 2018; Published: June 25, 2018 
months of gestation. No tissue was karyotyped, and no DNA was banked from any of the fetuses. The sixteenth pregnancy was revealed by ultrasound to be a female fetus with severe cardiac and neurological anomalies. The patient miscarried in the fourth month of gestation and no DNA was obtained. The seventeenth pregnancy was also a female fetus with severe cardiac anomalies and was miscarried in the fourth month of gestation. No DNA was obtained.

The couple underwent full laboratory investigations. All of the investigations of the wife (Table 1) and husband (Table 2) came back normal. Due to the couples' lineage being complicated by multiple loops of consanguinity, and their normal karyotype and chromosomal microarray results, it was decided that whole exome sequencing (WES) would be a suitable option for the couple to help reach a correct, and accurate diagnosis. The couple was counselled about the advantages and disadvantages of WES and they agreed to have proceed with the investigation.

The WES revealed that both the husband and the wife were carriers of mosaic variegated aneuploidy genes CEP57.

Table 1. Investigation results of the wife

Chromosome Analysis and peripheral blood using G-banding technique:

Banding: $\mathrm{G}$

Chromosome number: 46

Autosomes: normal

Sex Chromosomes: XX

Mutation screening:

Screening for G1619 à A mutation in factor V Leiden G20210 à A mutation in prothrombin genes.

The patient is not a carrier of any of the above-mentioned mutations.

Hematology:

\begin{tabular}{|c|c|c|c|}
\hline PT INR (ACT TOP 500) & 1.08 & $0.88-1.13$ & INR \\
\hline *PT Patient & 15.5 & $13-16$ & seconds \\
\hline *APTT Patient & 32.6 & $26-34.4$ & seconds \\
\hline *APTT Ratio & 1.09 & $0.87-1.13$ & (Ratio) \\
\hline PROTEIN S ACTIVITY & 93.8 & $63.5-149$ & $\%$ \\
\hline \multicolumn{4}{|l|}{ CBC: } \\
\hline WBC & 5.8 & $4.1-11.2$ & $109 / \mathrm{L}$ \\
\hline $\mathrm{RBC}$ & 4.12 & $3.83-5.08$ & $1012 / \mathrm{L}$ \\
\hline HEMOGLOBIN & 119 & $117-155$ & $\mathrm{~g} / \mathrm{L}$ \\
\hline HEMATOCRIT & 0.361 & $0.345-0.463$ & $\mathrm{~L} / \mathrm{L}$ \\
\hline $\mathrm{MCV}$ & 87.6 & $80.4-95.9$ & $\mathrm{fL}$ \\
\hline $\mathrm{MCH}$ & 28.8 & $27.2-33.5$ & pg \\
\hline $\mathrm{MCHC}$ & 329 & $325-352$ & $\mathrm{~g} / \mathrm{L}$ \\
\hline RDW & 13.5 & $11.7-14.6$ & $\%$ \\
\hline PLATELET COUNT & 279 & $150-410$ & $109 / \mathrm{L}$ \\
\hline MPV & 8.5 & $6.5-11.6$ & $\mathrm{fL}$ \\
\hline NEUTROPHILS \% & 44.4 & $39.9-73.9$ & $\%$ \\
\hline LYMPHOCYTES \% & 41.7 & $18.8-50.8$ & $\%$ \\
\hline MONOCYTES \% & 9 & $4.1-12.2$ & $\%$ \\
\hline EOSINOPHILS \% & 4.3 & 01-06 & $\%$ \\
\hline BASOPHILS \% & 0.6 & $0.3-1.8$ & $\%$ \\
\hline NEUTROPHILS \# & 2.6 & $1.8-6.4$ & $109 / \mathrm{L}$ \\
\hline LYMPHOCYTES \# & 2.4 & $1.2-3.6$ & $109 / \mathrm{L}$ \\
\hline MONOCYTES \# & 0.5 & $0.3-0.9$ & $109 / \mathrm{L}$ \\
\hline EOSINOPHILS \# & 0.2 & $0.1-0.5$ & $109 / \mathrm{L}$ \\
\hline BASOPHILS \# & 0 & $0-0.02$ & $109 / \mathrm{L}$ \\
\hline NUCLEATED RBC & 0 & & WBC \\
\hline \multicolumn{4}{|l|}{ Antibody screening: } \\
\hline \multicolumn{2}{|c|}{ Done by IF } & \multicolumn{2}{|c|}{ ENA profile (by IMMCO) } \\
\hline
\end{tabular}


Aljaser MT (2018) The use of whole exome sequencing to identify carriers of Mosaic Variegated Aneuploidy (MVA): A case study

\begin{tabular}{|c|c|c|c|c|c|c|c|c|}
\hline \multicolumn{2}{|l|}{ Anti-DNA } & & NEGATIVE & & Anti-SS (RO) 52 & \multicolumn{3}{|c|}{ NEGATIVE } \\
\hline \multicolumn{2}{|l|}{ C-ANCA } & & NEGATIVE & & nti- SSA (RO) 60 & \multicolumn{3}{|c|}{ NEGATIVE } \\
\hline \multicolumn{2}{|l|}{ P-ANCA } & & NEGATIVE & & Anti- SSB (LA) & \multicolumn{3}{|c|}{ NEGATIVE } \\
\hline \multicolumn{2}{|l|}{ Anti-TG } & & NEGATIVE & & Anti Smith (Sm) & \multicolumn{3}{|c|}{ NEGATIVE } \\
\hline \multicolumn{2}{|l|}{ LKM } & & NEGATIVE & & nti U1-sn RNP 68 & \multicolumn{3}{|c|}{ NEGATIVE } \\
\hline \multicolumn{2}{|l|}{ ASMA } & & NEGATIVE & & nti U1-sn RNP A & \multicolumn{3}{|c|}{ NEGATIVE } \\
\hline \multicolumn{2}{|l|}{ Anti-MITO } & & NEGATIVE & & nti U1-sn RNP C & \multicolumn{3}{|c|}{ NEGATIVE } \\
\hline \multicolumn{2}{|l|}{ Parietal cell } & & NEGATIVE & & Anti JO-1 & \multicolumn{3}{|c|}{ NEGATIVE } \\
\hline \multicolumn{2}{|c|}{ Anti-Endomysial } & & NEGATIVE & Anti SS & CL-70 Topoiosmerase & \multicolumn{3}{|c|}{ NEGATIVE } \\
\hline \multicolumn{2}{|c|}{ Anti-islet cell } & & NEGATIVE & & Anti PM-SCL 75 & \multicolumn{3}{|c|}{ NEGATIVE } \\
\hline & & & & & nti PM-SCL 100 & \multicolumn{3}{|c|}{ NEGATIVE } \\
\hline & & & & & Anti CENP B & \multicolumn{3}{|c|}{ NEGATIVE } \\
\hline & & & & & Anti HISTONE & \multicolumn{3}{|c|}{ NEGATIVE } \\
\hline & & & & & Anti RIBO-P & & NEG & TIVE \\
\hline & & & & & Anti PCNA & & NEG & TIVE \\
\hline Antibody screening: & & & & & & & & \\
\hline & & & & Dine & by ELISA technique & & & \\
\hline & Normal $R_{c}$ & & & & & & & \\
\hline Anti ds-DN & & & $<60 \mathrm{IU} / \mathrm{ml}$ & & ti GLIADIN IgA & & $<25$ & $\mathrm{U} / \mathrm{ml}$ \\
\hline P-ANCA & & & $<12.5 \mathrm{IU} / \mathrm{ml}$ & & ti GLIADIN IgG & & $<25$ & $\mathrm{U} / \mathrm{ml}$ \\
\hline C-ANCA & & & $<12.5 \mathrm{IU} / \mathrm{ml}$ & & Anti MITO & & $<25$ & $\mathrm{U} / \mathrm{ml}$ \\
\hline Anti CL-IgA & & & $<22 \mathrm{APL} / \mathrm{ml}$ & & Anti SPERM & & & $\mathrm{J} / \mathrm{ml}$ \\
\hline Anti CL-IgG & & & $<\mathrm{GPL} / \mathrm{ml}$ & & Anti H Pylori & & $<50$ & \\
\hline Anti CL-IgM & & & $11 \mathrm{MPL} / \mathrm{ml}$ & & Anti GBM & & $<25$ & $\mathrm{U} / \mathrm{ml}$ \\
\hline Anti B2GL-Ig & & & $<9 \mathrm{U} / \mathrm{ml}$ & & Anti ss-DNA & & $<20$ & $\mathrm{U} / \mathrm{ml}$ \\
\hline Anti B2GL-IgC & & & $<25 \mathrm{EU} / \mathrm{ml}$ & & ti Intrinsic factor & & $<25$ & $\mathrm{U} / \mathrm{ml}$ \\
\hline Anti B2GL-IgN & & & $<25 \mathrm{EU} / \mathrm{ml}$ & & entromere Ab's & & $<25$ & $\mathrm{U} / \mathrm{ml}$ \\
\hline RF IgA & & & $<20 \mathrm{U} / \mathrm{ml}$ & & ti Parietal cell Ab & & $<25$ & $\mathrm{U} / \mathrm{ml}$ \\
\hline RF IgG & & & $<20 \mathrm{U} / \mathrm{ml}$ & & Anti IA2 & & $<7.5$ & $\mathrm{~J} / \mathrm{ml}$ \\
\hline RF IgM & & & $<14 \mathrm{U} / \mathrm{ml}$ & & Anti GAD & & & \\
\hline Anti CCP & & & $<50 \mathrm{U} / \mathrm{ml}$ & & Anti Insulin & & $<10$ & $\mathrm{~J} / \mathrm{ml}$ \\
\hline Anti TPO & & & $<75 \mathrm{IU} / \mathrm{ml}$ & & & & & \\
\hline Anti TG & & & $<100 \mathrm{IU} / \mathrm{ml}$ & & & & & \\
\hline & & & & & yroid function test: & & & \\
\hline & & & Result Value & & Ref. Range & & & \\
\hline FRT4 & & & 18.17 & & $12-22$ & & & \\
\hline PRL & & & 228.9 & & $72-511$ & & & \\
\hline TSH & & & 2.25 & & $0.27-4.2$ & & & \\
\hline FREE T3 & & & 4.88 & & $5.4-12.3$ & & & \\
\hline & & & & & Whole Exome Seq & & & \\
\hline Gene & Nucleotide & & Zygosity & Described & In silico parameters & MAF & ation & Disorder (OMIM\#, inheritance) \\
\hline (Transcript) & (protein) & Husband & wife & by $5 y^{2}$ & ill sintivo paranterts & 列 & & S \\
\hline CEP57 (NM_014679.4) & c.56del & Het. & Het. & $\begin{array}{c}\text { Not } \\
\text { described }\end{array}$ & Frameshift & $\begin{array}{l}\text { Not } \\
\text { reported }\end{array}$ & & $\begin{array}{l}\text { Mosaic Variegated aneuploidy } \\
\text { synddrome-2 }(614114, \mathrm{AR})\end{array}$ \\
\hline
\end{tabular}


Table 2. Investigation results of the husband

\begin{tabular}{|c|c|c|c|c|c|c|c|c|}
\hline \multicolumn{9}{|c|}{ Whole Exome Sequencing: } \\
\hline \multirow{2}{*}{$\begin{array}{c}\text { Gene } \\
\text { (Transcript) }\end{array}$} & \multirow{2}{*}{$\begin{array}{c}\text { Nucleotide } \\
\text { (protein) }\end{array}$} & \multicolumn{2}{|c|}{ Zygosity } & \multirow{2}{*}{ Described by } & \multirow{2}{*}{ In silico parameters } & \multirow{2}{*}{ MAF } & \multirow{2}{*}{ Variant classification } & \multirow{2}{*}{$\begin{array}{c}\text { Disorder (OMIM\#, } \\
\text { inheritance) }\end{array}$} \\
\hline & & Husband & wife & & & & & \\
\hline $\begin{array}{c}\text { CEP57 } \\
\text { (NM_014679.4) }\end{array}$ & c.56del & Het. & Het. & Not described & Frameshift & Not reported & $\begin{array}{l}\text { Likely pathogenic } \\
\text { (class 2) }\end{array}$ & $\begin{array}{l}\text { Mosaic Variegated } \\
\text { aneuploidy } \\
\text { synddrome-2 } \\
(614114, \mathrm{AR})\end{array}$ \\
\hline \multicolumn{9}{|c|}{$\begin{array}{l}\text { Chromosome Analysis and peripheral blood using G-banding technique: } \\
\text { Banding: G } \\
\text { Chromosome number: } 46 \\
\text { Autosomes: normal }\end{array}$} \\
\hline
\end{tabular}

\section{Management and outcome}

Taking into consideration the fact that both patients are confirmed carriers of MVA CEP57 gene, the previous fourteen consecutive miscarriages, the mothers age, and the social and cultural background of the couple. It was decided that Invitro Fertilization (IVF) and preimplantation genetic diagnosis (PGD) would be the most appropriate solution if they intended to continue growing their family. Ultimately, the couple decided that they wanted to initiate the IVF-PGD process.

\section{Discussion}

The presentation and the pedigree of the case was unique. While the couple presented to the clinic to address recurrent miscarriages, the lack of fetal tissue, the lack of clinically significant lab results, in addition to the multiple consanguineous loops (Figure 1) made reaching a diagnosis difficult.

It was approached as a case of infertility. The patients underwent assessment for structural anomalies which returned normal. The hormonal profiles of the couple were normal. The Immunology panel including anti-dsDNA, anti-TPO, anti-TG, anti-cardiolipin, antiphospholipid, and anti-ssDNA, as well as the hematological results, were normal.

The treating team decided to proceed to genetic testing of both patients. The karyotype of the wife and husband was normal. Chromosomal microarray identified homozygosity compromising about $2.26 \%$ of the genome, which does not match the percentage of homozygosity expected of a first-degree cousin marriage who have multiple loops of consanguinity in their family history [5].

The couple agreed to WES and the results showed that both the husband and wife were carriers for the pathogenic CEP57 gene mutation, making them both carriers of type 2 mosaic variegated aneuploidy syndrome. Coincidentally, they were carriers of a previously unreported heterozygous variant in the CEP57 gene. The Exome aggregation consortium had no previous record of this variant and at the time of detection, this variant had not been listed in CentoMD ${ }^{\circ}$

This CEP57 mutation creates a frameshift at the Ala19 and a stop codon 18 positions downstream that likely leads to truncation of the translated protein. MVA type 2 is known to be an autosomal recessive syndrome which results in defective cell division. The resultant chromosomal disjunction during mitosis leads to a variety of phenotypic abnormalities [6]. Unlike MVA type 1, MVA type 2 patients usually have normal head circumferences and slow growth rates. Additionally, MVA type 2 has been associated with shorter upper limbs [2].

This is the first time reporting a couple who are both carriers of the same new variant of the CEP57 mutation and is also the first time reporting multiple successive miscarriages caused by MVA type 2 .

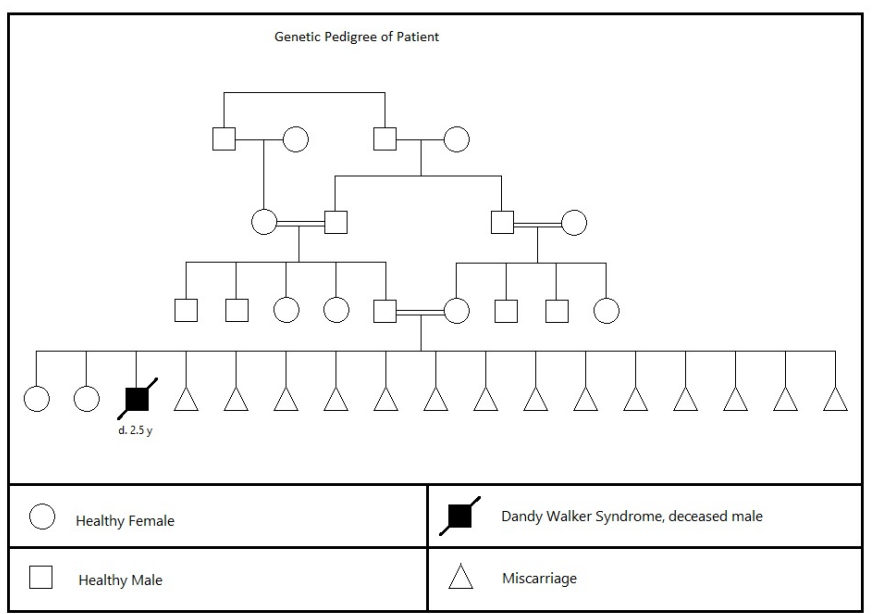

Figure 1. The genetic pedigree of the patients

The occurrence of this case may be attributed to the high rates of consanguineous marriages in the Middle East, which was estimated to be between 30 to $50 \%$ or more of the population [7]. These rates are greatly influenced by the cultural traditions and social customs of the area [7]. It is customary among the Bedouin and tribal families of the region to marry first cousin to first cousin. As a consequence of these marriages, there are higher rates of genetic diseases in these areas [7]. The only way to impact the high rates of inherited genetic syndromes in these groups would be to focus on educating the population on the risks and potential outcomes of these marriages, focusing on counselling families that are known to be carriers of genetic syndromes about the risks involved in consanguineous marriages, and by establishing governmental programs that screen for the most common genetic diseases.

\section{References}

1. Hanks S, Snape K, Rahman N (2012) Mosaic variegated aneuploidy syndrome. Atlas Genet Cytogenet Oncol Haematol 16: 376-380.

2. García-Castillo H, Vásquez-Velásquez AI, Rivera H, Barros-Núñez P (2008) Clinical and genetic heterogeneity in patients with mosaic variegated aneuploidy: delineation of clinical subtypes. Am J Med Genet A 146A: 1687-1695. [Crossref]

3. Mosaic variegated aneuploidy syndrome (2012) Online Mendelian Inheritance in Man

4. Meunier S, Navarro MG, Bossard C, Laurell H, Touriol C, et al. (2009) Pivotal role of translokin/CEP57 in the unconventional secretion versus nuclear translocation of FGF2. Traffic 10: 1765-1772. [Crossref]

5. Woods C, Cox J, Springell K, Hampshire D, Mohamed M, et al. (2006) Quantification of homozygosity in consanguineous individuals with autosomal recessive disease. $\mathrm{Am}$ J Hum Genet 78: 889-896. 
Aljaser MT (2018) The use of whole exome sequencing to identify carriers of Mosaic Variegated Aneuploidy (MVA): A case study

6. Pinson L, Mannini L, Willems M, Cucco F, Sirvent N, et al. (2014) CEP57 mutation in a girl with mosaic variegated aneuploidy syndrome. Am J Med Genet A 164A: 177181. [Crossref]
7. Bittles AH, Black ML (2010) Evolution in health and medicine Sackler colloquium: Consanguinity, human evolution, and complex diseases. Proc Natl Acad Sci U S A 107 1779-1786. [Crossref]

Copyright: (C2018 Aljaser MT. This is an open-access article distributed under the terms of the Creative Commons Attribution License, which permits unrestricted use, distribution, and reproduction in any medium, provided the original author and source are credited. 